\title{
ACTIVE LEARNING TECHNIQUES IN ENGINEERING EDUCATION
}

\author{
Anitha H M $\mathbf{M}^{1}$, Anusha N Rao \\ ${ }^{1}$ Department of Information Science and Engineering, BMS College of Engineering, Bangalore, India \\ ${ }^{2}$ Department of Information Science and Engineering, BMS College of Engineering, Bangalore, India
}

\begin{abstract}
The current developments in technology and ideas have given entirely new dimensions to the field of research and education. New delivery methods are proposed which is an added feature to the engineering education. Particularly, more importance is given to new teaching practices such as Information and Communication Technologies (ICT). It is vital to adopt the new ICT methods which lead to emergence of novel structure and mode of education. The flipped classroom, think pair share and peer instruction are the latest pedagogical methods which gives students to learn the course. This involves students to watch video lectures outside the classroom and solve the problems at home. Students are engaged in group discussions in the classroom. These are the active learning methods where in student is involved diversely to learn the course. This paper gives a comprehensive study of past and present researches which is going on with flipped class room, thinks pair share activity and peer instruction.
\end{abstract}

Keywords-Flipped classroom; Think pair share; Peer instruction; Active learning. - $* * *$

\section{INTRODUCTION}

Traditional teaching methods are been practiced from many generations where in student sit silently and grasp the contents delivered by the teacher in the classroom [1]. All the students are delivered with same content, material at the same time. Active teaching starts before the teacher enters the classroom. Teacher should set the learning objectives and devise methods to achieve these objectives before delivering the topic to the students. Traditional methods focused mostly on rote learning and memorization should be neglected in favour of students and implement new approaches like flipped classroom and think pair share activity to improve active learning.

Some of the Traditional delivery methods are

- $\quad$ Black Board and chalk piece: Use of black board teaching to effectively convey the students with topic.

- Power point presentations: It gives the pictorial view of the content more clearly.

- Laboratory instruction: Gives the students with hands on knowledge of the topic.

- Industrial visits: Enriches the students with the actual application of theoretical concepts learnt in the classroom.

There are advantages and disadvantages of traditional teaching methods which are listed below.

Advantages of traditional methods

- Teacher gives contents to the students which are not exposed to them before.

- In laboratory based methods students are exposed to real time examples demonstrated by the teacher.

- Content is delivered to many students at the same time.
Disadvantages of traditional methods

- Facilitates passive learning for the students.

- Only one way communication and it takes lot of effort by the teacher to involve the students.

The introduction of latest technologies led to the active learning of students in engineering education. Flipped class room, think pair share and peer instruction are the new methods that give more active learning for students.

\section{LITERATURE SURVEY}

Dimitrios, et.al [1], gave the idea that despite traditional teaching methods, growth in technology has motivated the teachers and students to adapt new teaching methods to improve the student learning and perfection. Traditional learning is more teacher centric whereas the new ICT methods are student oriented. The new teaching methods used may differ in terms of the level of influence on learning.

Bishop et.al [2], provides insight about the current research about the flipped classroom. It includes evaluation of activities which are conducted inside and outside the class. Flipped classroom gives unique combination of learning concepts like active learning; problem based learning and mini projects.

Slone et.al [6], used simple online tools which provides platform for application of think pair share activities. A set of psychological students were given with clinical case study. They were asked to record their particular diagnosis on the Google doc. Each group shared their results about their activity in the class. Teachers reviewed the findings of the students. This online tool adaptation for TPS activity offers in-depth knowledge of the course and provides them chance to discuss in pairs and share their results to the whole class. 
Crouch, Catherine H., et al [8], implemented the peer instruction idea in their classroom and results were shown that students gained mastery over the course. Outcome of learning is improved compared to traditional method. They gave the idea how teachers had success using peer instruction method and students attainment in course drastically more.

\section{FLIPPED CLASSROOM}

The flipped classroom is a teaching method which allows teachers to involve students actively in the classroom [2][3]. Teachers provide recorded video tutorials to the students as homework and use class time for solving the problems and exercises. Flipped classrooms help two way communications between teacher and student. It improves interpersonal and intrapersonal skills of the students.

Though there is lot of discussions around flipped classroom which is latest topic in educational research, there is lack awareness of what flipped classroom is and how to implement the ideology in to current curriculum. The definition is "the flipped classroom is a form of blended learning which describes a reversal of traditional teaching where students gain first exposure to new topic outside the class, usually via reading or lecture videos, and then class time is used to do the harder work of assimilating that knowledge through strategies such as problem-solving, discussion or debates" [4].The Fig. 1 depicts the flipped concept which is new pedagogical method.
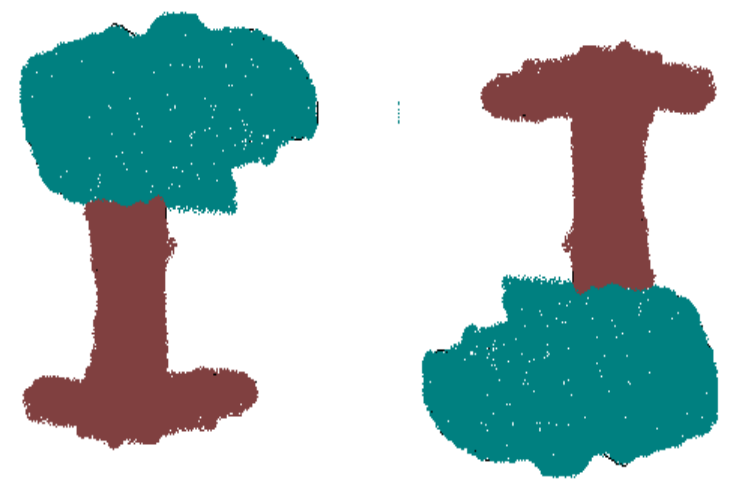

Fig. 1 Flipped view

Table 1 Comparison of traditional classroom and flipped classroom

\begin{tabular}{|c|c|}
\hline \\
\hline Traditional clas & Flipped classroom \\
\hline $\begin{array}{l}\text { Homework given in the } \\
\text { previous class }\end{array}$ & $\begin{array}{l}\text { First videos are given to } \\
\text { understand }\end{array}$ \\
\hline Topic is taught in the class & $\begin{array}{l}\text { Active learning of topic via } \\
\text { activities }\end{array}$ \\
\hline $\begin{array}{l}\text { Deeper understanding via } \\
\text { homework }\end{array}$ & $\begin{array}{l}\text { Some homework and } \\
\text { learning new topic }\end{array}$ \\
\hline
\end{tabular}

Scenario of Flipped classroom: Outside the classroom: Students are assigned with packet switching technology video lecture.
Learning Objective: Students should be able understand different packet switching methods

Class room activity: Solve different switching network problems and compare delays of message switching, virtual circuit switching and packet switching.

\section{Advantages of flipped classrooms}

- Outcomes in education is improved

- Efficient utilization of time

- Active learning is achieved

- Multiple submissions improve attainment level of students

- $\quad$ Learning involves students

- $\quad$ Perfection in learning

The steps of flipped classroom are shown in the Fig. 2 are described

- $\quad$ Students are assigned with reading or video lectures of the content to learn outside the classroom as a home assignment.

- Classroom is used to discuss the exercise problems and solve them with some activities like quiz, group discussions and mini projects.

- Students go back to home and solve some more assignments and prepare for next topic assigned by the teacher.

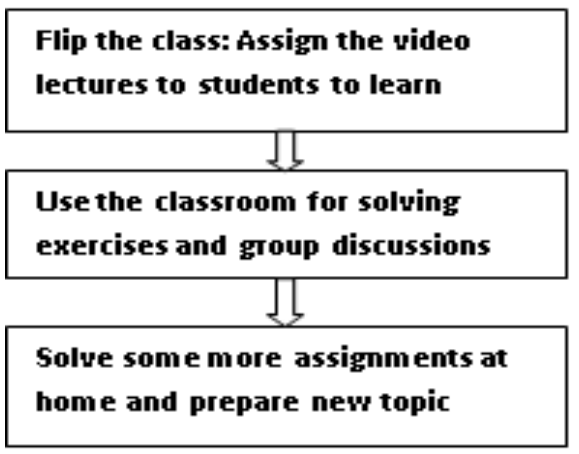

Fig 2 Steps involved in flipped classroom method

\section{THINK PAIR SHARE}

Think-pair-share (TPS) is a combined knowledge scheme where a teacher initiates a problem and students pair with each other to solve it and share their insights to the class [6]. This scheme uses three steps for active learning in class as shown in Fig. 3. Firstly, teacher presents a problem or a question and students think individually. Secondly, a student is paired with another student or a small group and they interact with each other and engage in solving the problem. Lastly, the teacher asks the students to share their thoughts about the solution to the problem. This strategy increases the degree of student participation, compared to the traditional method where teacher poses a question and one student answers it. Further, it encourages students to share their thoughts with at least one other student and allow them to involve more in classroom activities. The teacher can interact with students in pairs and answer to them accordingly. 


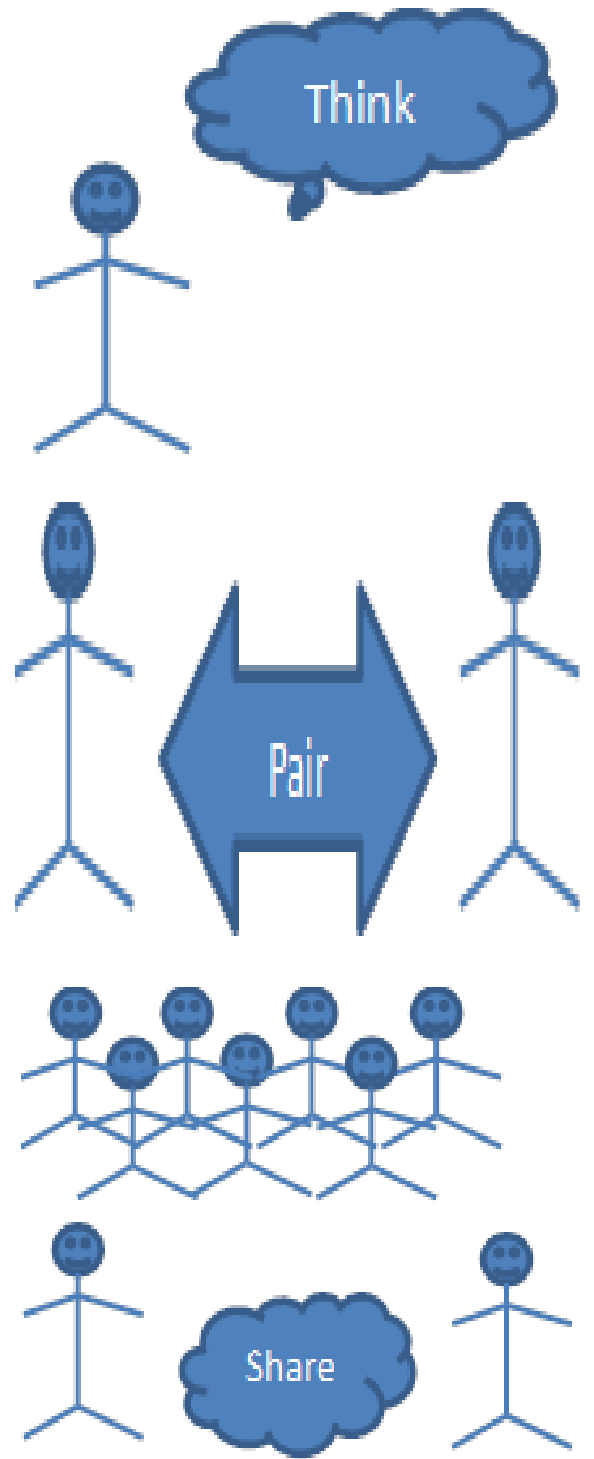

Fig 3 Think pair share scheme

Scenario of TPS activity: Engineering students were given a problem in java programming.

Learning outcome: Student should be able to write the program in java for a given task.

Problem statement: Recall the string methods to apply on sorting names and search for a given name using binary search.

Think: Individually write pseudo-code for sorting and searching.

Share: Teacher collects the solutions from the students and summarizes one solution for the given problem.

Advantages of TPS techniques are:

- Students are actively involved in the class.

- Helps to develop in-depth knowledge of the topic

- Students develop communication skills

- Helps students to ask question which they normally do not ask individually.
- $\quad$ Easy to use for big classrooms

- Student learning is superior by the clarification of the topic.

- Helps in improving the outcome of the course.

\section{PEER INSTRUCTION}

Peer Instruction is evidence based active learning pedagogical method which can be applied in engineering education. Peer instruction is a new teaching method where students learn the content outside the classroom and answer the questions with the topic posed by the teacher. It is an active learning method in which students are engaged actively. Students take some time to formulate the answers and discuss in groups to arrive at the results. According to [7] the questioning procedure outlined as follows:

- Teacher asks question based on the students understanding of concept outside the class.

- Students individually answer the question.

- Teacher reviews the answers of the students.

- $\quad$ Students are then engaged in group discussions and respond to the question along with peers.

- Teacher again reviews the answers and explain the concept to the students before proceeding to next topic.

Scenario of PI activity: Engineering students were given with PI question to answer.

Learning Outcome: Students should be able understand the array concept in java.

PI question: Which is the correct method of creating an array of integers?
a. javaArr $=$ new int $[10]$
b. javaarr new $=$ myarray $[10]$
c. int[] javaArr =new int[10]
d. A and C Both

Advantages of PI activity [8] are:

- Student engagement is increased.

- In depth understanding of topic is achieved.

- Student performance is increased as content is memorized thoroughly.

- Course outcome is improved.

\section{CONCLUSION}

The new delivery methods have to be adapted in the engineering education. It is important to implement the information and communication methods like flipped classroom, think pair share and peer instruction. By including these methods in the curricula, learning process of the students will be more effective and interesting. We have made a study of the flipped classroom, think pair share and peer instruction in this paper to adapt for engineering education. 


\section{ACKNOWLEDGMENTS}

The authors would like to acknowledge and thank Technical Education Quality Improvement Program (TEQIP) phase-II, B. M. S. College of Engineering and Static Project Facilitation Unit (SPFU), Karnataka for supporting the research work.

\section{REFERENCES}

[1] Dimitrios, B., Labros, S., Nikolaos, K., Maria, K., \& Athanasios, K. "Traditional Teaching Methods VS. Teaching through the application of the Information and Communication Technologies in the accounting field:Quovadis?" European Scientific Journal 9.28 (2013).

[2] Bishop, J. L., \& Verleger, M. A.. "The flipped classroon: A survey of the research." ASEE National Conference Proceedings,Atlanta,GA,2013

[3] Flipped Class Room Guide, http://www.cvm.umn.edu/facstaff/prod/groups/cvm/ @ pub/@cvm/@facstaff/documents/content/cvm_co ntent_454476.pdf, Accessed on $27^{\text {th }}$ October, 2014.

[4] Flipped class rooms, University of Queensland, http://www.uq.edu.au/tediteach/flipped-

classroom/what-is-fc.html. Accessed on $27^{\text {th }}$ October, 2014.

[5] Slone, Norah C., and Nathanel G. Mitchell. "Technology-based adaptation of think-pair-share utilizing Google drive." Journal of Teaching and Learning with Technology 3.1 (2014): 102-104.

[6] Think Pair Share, http://www.readingrockets.org/strategies/think-pairshare, Accessed on $28^{\text {th }}$ October, 2014.

[7] Eric, M. Peer Instruction: A User's Manual Series in Educational Innovation. Prentice Hall, Upper Saddle River, NJ, 1997.

[8] Crouch, C. H., Watkins, J., Fagen, A. P., \& Mazur, E. "Peer instruction: Engaging students one-on-one, all at once." Research-Based Reform of University Physics 1.1, 40-95, 2007. 